\title{
Evaluation of psychological resilience and anxiety levels of patients with hyperemesis gravidarum diagnosis and comparison with healthy pregnant women
}

\author{
Hiperemezis gravidarum tanıl hastaların psikolojik \\ dayanıklılı ve anksiyete düzeylerinin değerlendirilmesi ve \\ sağlıklı gebe kadınlarla karşılaştırılması
}

\author{
(1) Burak Elmas ${ }^{1}$, (1) Merve Vatansever ${ }^{2}$, (1) Aybeniz Civan Kahve ${ }^{3}$, (1) Burçin Salman Özgü4, (1) Gonca Asut ${ }^{5}$, \\ (1) Işıı Batuhan Çakmak ${ }^{3}$, (1) Ayşegül Bestel ${ }^{6}$, (1) Salim Erkaya ${ }^{7}$ \\ ${ }^{1}$ Private Olbamed Hospital, Clinic of Obstetrics and Gynecology, Mersin, Turkey \\ ${ }^{2}$ Ankara University Institute of Forensic Sciences, Departmant of Forensic Psychology, Ankara, Turkey \\ ${ }^{3}$ Ministry of Health Ankara City Hospital, Clinic of Psychiatry, Ankara, Turkey \\ ${ }^{4}$ Ministry of Health Ankara City Hospital, Clinic of Obstetrics and Gynecology, Ankara, Turkey \\ ${ }^{5}$ Tekirda ğ State Hospital, Clinic of Psychiatry, Tekirdağ, Turkey \\ ${ }^{6}$ University of Health Sciences Turkey, Kanuni Sultan Süleyman Training and Research Hospital, Clinic of Obstetrics and Gynecology, İstanbul, Turkey \\ ${ }^{7}$ University of Health Sciences Turkey, Ankara Etlik Zübeyde Hanım Women's Health Training and Research Hospital, Clinic of Obstetrics and Gynecology, \\ Ankara, Turkey
}

\begin{abstract}
Objective: To compare the psychological resilience and anxiety levels of patients diagnosed with hyperemesis gravidarum (HG) and healthy pregnant women.

Materials and Methods: A sociodemographic data form and the Resilience scale for Adults (RSA) and the State-Trait Anxiety Inventory (STAI) were administered. The sociodemographic data form was completed by the physician, and the RSA and STAI were completed by the participant. The sample of the study consisted of 60 pregnant women with HG and hospitalized and 97 healthy voluntary pregnant women with similar characteristics to the research group without any pregnancy complications. Data were evaluated using descriptive statistical analyses, the independent samples t-test, the Mann-Whitney U test and Pearson's correlation analysis.

Results: The age range was 18-42 years for HG group and 20-43 years for control group. The average age of the HG group was $28.17 \pm 5.96$ years and that of the control group was $29.45 \pm 5.83$ years. There was no statistically significant difference between the groups in terms of pregnancy week. Regarding the prevalence of state and trait anxiety between the groups, it was found that $66.7 \%$ of the HG group had a high level of trait anxiety and $51.7 \%$ had a high level of state anxiety. It was found that $61.9 \%$ of the control group had a high level of trait anxiety and $38.1 \%$ had a high level of state anxiety. There was no difference between the healthy pregnant group and the HG group in terms of anxiety $(\mathrm{p}=0.125)$. It was found that there was a significant difference between the groups in terms of only sub-dimensions of RSA, which were perception of self $(\mathrm{U}=2385.00, \mathrm{p}=0.044)$ and perception of future ( $\mathrm{U}=2350.50$, $\mathrm{p}=0.030$ ). The perception of self and perception of future scores of the healthy control group were higher.

Conclusion: There was no difference between the healthy pregnant group and the HG group in terms of anxiety. It was observed that the HG group had a lower perception of self and future. Apart from the usual increase in anxiety levels during pregnancy, HG accompanied by stubborn nausea and vomiting does not create an extra psychological burden, either as a cause or a result.
\end{abstract}

Keywords: Hyperemesis gravidarum, pregnancy, resilience, anxiety

PRECIS: Using the Resilience scale for Adults and State-Trait Anxiety inventory, we compared normal pregnant women with hyperemesis gravidarum in terms of psychological resilience and anxiety.

Address for Correspondence/Yazışma Adresi: Burak Elmas MD, Private Olbamed Hospital, Clinic of Obstetrics and Gynecology, Mersin, Turkey Phone: +90 5372367365 E-mail: burak_elmas88@hotmail.com ORCID ID: orcid.org/0000-0001-7977-4364

Received/Geliş Tarihi: 21.03.2021 Accepted/Kabul Tarihi: 05.05.2021

${ }^{\circledR}$ Copyright 2021 by Turkish Society of Obstetrics and Gynecology

Turkish Journal of Obstetrics and Gynecology published by Galenos Publishing House. 


\section{$\mathrm{O} z$}

Amaç: Çalışmanın amacı hiperemezis gravidarum (HG) tanısı alan hastaların psikolojik dayanıklılıkları ve kaygı düzeylerinin sağlıklı gebeler ile karşılaştırılmasıdır.

Gereç ve Yöntemler: Sosyodemografik veri formu, Yetişkinler İçin Psikolojik Dayanıklılık ölçeği (YİPDÖ) ve Durumluk Sürekli Kaygı ölçeği (DSKÖ) uygulanmıştır. Sosyodemografik Veri Formu klinisyen tarafından, YIPDÖ ve DSKÖ ise katılımcı tarafından doldurulmuştur. Çalışmanın örneklemini, HG tanısı alan ve hastaneye yatırılmış 60 gebe ve herhangi bir gebelik komplikasyonu olmayan, araştırma grubu ile benzer özellikte 97 sağlıklı gönüllü gebe oluşturmaktadır. Veriler betimsel istatistiksel analizler, Bağımsız Örneklemler t-testi, Mann-Whitney U ve Pearson korelasyon analizi ile değerlendirilmiştir.

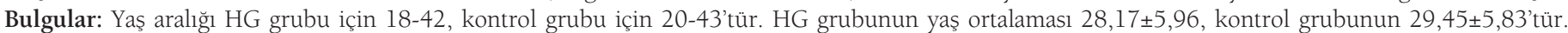
Gebelik haftası yönünden gruplar arasında istatistiksel olarak anlamlı fark görülmemiștir. DSKÖ'nün her iki grup arasındaki yaygınlığına bakıldığında, HG'li grubun \%66,7'sinün yüksek sürekli kaygıya düzeyine, \%51,7'sinin yüksek durumluk kaygı düzeyine sahip oldukları bulunmuştur. Kontrol grubunun \%61,9'unun yüksek sürekli kaygıya düzeyine, \%38, l'inin yüksek durumluk kaygı düzeyine sahip oldukları bulunmuştur. YİPDÖ alt boyutlarından sadece kendilik algısı ve gelecek algısı açısından gruplar arasında anlamlı farklılık bulunmuştur. Sağlıklı kontrol grubunun kendilik algısı ve gelecek algısı puanlanı daha yüksektir.

Sonuç: Sağlıklı gebe grubuyla HG grubu arasında kaygı düzeyi açısından fark görülmemektedir. HG grubunun kendilik ve gelecek algısının daha düşük olduğu görülmüştür. Gebelikte olağan kaygı düzeyi artışı haricinde, inatçı bulantı kusmaların eşlik ettiği HG durumu hem sebep olarak hem de sonuç olarak fazladan bir psikolojik yük oluşturmamaktadır.

Anahtar Kelimeler: Hiperemezis gravidarum, gebelik, psikolojik dayanıklılık, kaygı

\section{Introduction}

Nausea and vomiting is a condition that affects the physical and psychological condition, and quality of life of pregnant women during pregnancy ${ }^{(1-3)}$. These symptoms become severe and deteriorate in $2 \%$ of pregnant women, and they are hospitalized because of hyperemesis gravidarum (HG) $)^{(1,4-}$ 6). HG is characterized by stubborn nausea and vomiting that may cause malnutrition requiring hospitalization and can result in dehydration ketonuria, electrolyte and metabolic disorders, and weight $\operatorname{loss}^{(7,8)}$. Various studies were conducted on the etiology of HG and it is now accepted that it is a psychosomatic disease caused by the interaction of biologic, psychological, and sociocultural factors ${ }^{(8,9)}$. HG is an uncontrollable, stressful, and distressing condition, and makes it difficult to be satisfied with treatment and care; therefore, women can be hospitalized several times during pregnancy ${ }^{(10)}$.

The fact that when vomiting and nausea will stop and how to manage this is unknown causes women to experience frustration, despair, weakness, and anxiety. Anxiety can exacerbate symptoms such as nausea and vomiting, and increased nausea and vomiting also increases anxiety levels. HG disrupts the life routine of pregnant women, making them unable to do daily work, and causing a sense of inadequacy ${ }^{(11)}$. On the other hand, pregnant women nurture concerns about both their own health and the health of their baby. The process may also cause that the thoughts of pregnant women about the future to change in a negative direction. With stubborn nausea and vomiting, which has already changed the body physiology significantly with the pregnancy process, when pregnant women have not fully adapted, the emotions and perceptions of pregnant women can change completely into fear, anxiety, and helplessness. In this respect, determining the challenging psychological factors emerging during the treatment of hospitalized patients with HG and developing support systems for them will have positive effects on the treatment process.

Psychological resilience (PR) is a general concept, and includes factors shown to be protective against psychological disorders, and is generally defined as "the power to recover oneself", "the ability to overcome disasters", or "the ability to adapt positively"(12). PR allows the individual to make use of social resources (family, friends), social adequacy (being extrovert, communication skills, flexibility in inter-personal relations, ability to establish close relations), personal resources (self-reliability, hope, realistic orientation towards life) simultaneously ${ }^{(13)}$.

PR was originally considered to be a personality trait, and some people were hypothesized to be inherently "resilient"; however, it was later considered to be "learnable" and "improvable" over time. For this reason, its implementation in treatment as an intervention strategy has come to the fore. Today, PD is considered in a multifaceted manner, allowing individuals to deal with challenging life events accurately, bringing together structural variables such as temperament and personality, as well as original abilities such as problem-solving ${ }^{(14)}$.

Anxiety and depression are commonly reported among pregnant women worldwide because the transition to motherhood is challenging, involving significant changes both physically and psychologically ${ }^{(15)}$. During this critical period, women are susceptible to the negative effect of life events that could result in prenatal anxiety or depression ${ }^{(16)}$. The etiology of HG remains unclear and may be multi-factorial with biologic, psychological, and socioeconomic antecedents ${ }^{(17)}$. Historically, a pregnant woman's vomiting was thought to represent various psychological conflicts. However, it is also plausible that psychological symptoms are a result of the stress and the physical burden of HG, rather than a cause ${ }^{(17)}$. Women with prior psychiatric or medical conditions are more likely to develop HG when pregnant ${ }^{(18)}$. The prevalence of major depression, generalized anxiety disorder, avoidant personality disorder, and obsessive-compulsive personality disorder is higher in women with $\mathrm{HG}^{(19)}$. In addition, for pregnant women, recent research found that resilience could affect sleep quality and mediate the relationship between maternal stress and sleep quality in pregnant women ${ }^{(20)}$. However, studies assessing resilience specifically in pregnant women and its impact on 
prenatal anxiety and depression are still lacking. Nonetheless, it was noted that no studies have evaluated the relationship between PR and the anxiety levels of individuals, and compared pregnant women with HG with healthy pregnant women. The purpose of the present study was to compare the PR and anxiety levels of patients with HG and healthy pregnant women.

\section{Materials and Methods}

\section{Participants}

This study was conducted between March 2019 and August 2019 in the Early Pregnancy Department. After the required approvals for the study were obtained from the institution (decision number: 90057706-799, date: 19.02.2019), the study was commenced. The sample of the study consisted of 157 participants, which included 60 voluntary patients who were admitted with HG in the first three months of pregnancy, and 97 healthy voluntary pregnant women with similar characteristics as the HG group, with no pregnancy complications. Informed consent of the participants was obtained. The inclusion criteria were having conceived willingly, ketone positivity in urine, and being hospitalized with a diagnosis of HG. The exclusion criteria were a diagnosis of psychiatric disease or receiving psychiatric treatment in the last year, alcohol or substance use disorder, presence of co-morbidities, presence of plural pregnancy, and having miscarriage history. The control group consisted of pregnant women who were admitted to the clinic for routine follow-up purposes.

Medical characteristics such as gestational week, parity, alcohol and smoking status, comorbid diseases, and surgical history were noted. In addition, the sociodemographic characteristics of the participants such as age, living quarters, economic status, and educational status were also recorded. The gestational weeks of the pregnant women were calculated according to their last menstrual periods. Educational status was classified as illiterate, primary school, high school, university, and doctorate. The economic situation was determined to be low, moderate, good, and very good with the answers given by the participant with the limits not determined by us, reflecting the participant's living standards and their own perception of their current economic situation. Family structure was classified as those living with their spouse, those living with their spouse and children, those living with extended families, and those living alone. Additional diseases of the participants were also questioned. Eight pregnant women in the HG group had additional diseases, as did 13 pregnant women in the control group. In the HG group, there was hypothyroidism $(n=2)$, asthma $(n=3)$, migraine $(n=2)$, and gastritis $(n=1)$, and in the healthy pregnant group, there was hypothyroidism $(n=4)$, migraine $(n=4)$, asthma $(n=1)$, irritable bowel syndrome $(n=2)$, vertigo $(n=1)$, and Behçet's disease $(n=1)$ noted in the medical history.

\section{Data Collection Tools}

\section{The Resilience Scale for Adults}

The Resilience scale for Adults (RSA) was developed by Friborg et al. ${ }^{(13)}$ When it was first developed, it had four sub-dimensions, personal power, structural style, social competence, and family agreement; however, the personal power sub-dimension was divided into two as perception of self and perception of future ${ }^{(21)}$. Thus, the scale consists of five sub-dimensions. The Turkish validity and reliability study was conducted by Basim and Cetin ${ }^{(22)}$. The scale consists of 33 items and is answered in a 5-point Likert scale. The Cronbach alpha reliability coefficient for the sub-dimensions varies between $0.66-0.81^{(22)}$.

\section{State-Trait Anxiety Inventory}

The scale was developed by Spielberg et al. ${ }^{(23)}$. State-Trait Anxiety inventory (STAI) consists of 40 items, 20 of which measure trait anxiety and 20 items measure state anxiety. The state anxiety subscale measures anxiety at the time when the scale is applied. The trait anxiety subscale measures the general anxiety trend. The scale is answered on a 4-point Likert-style scale, and high total scores show that the level of anxiety is increased. The total score obtained from the subscales varies between 20 and 80 . The mean score in applications varies between 36 and 41. A score of 36 and below indicates mild anxiety, 37-41 moderate anxiety, and 42 and above indicate high anxiety levels. The Turkish validity and reliability study of the scale was conducted by Oner and LeCompte ${ }^{(24)}$ Pearson's coefficient was calculated between 0.26 and 0.68 for the state anxiety scale and 0.71 to 0.86 for Trait Anxiety scale in the test re-test reliability study.

\section{Procedure}

Volunteering participants gave informed consent for the study. Each completed a Sociodemographic data form, the RSA, which consisted of 33 questions, and the STAI, which had two components consisting of 20 questions. The sociodemographic data form was filled out by the physicians and the RSA and STAI were completed by the participants.

\section{Statistical Analysis}

Whether the distribution of the continuous numerical variables was normal was examined using the Kolmogorov-Smirnov test. The Levene test was used to check whether the assumption of homogeneity was met by the variances. Descriptive statistics are expressed as mean, standard deviation (SD) $( \pm)$ or median (minimum-maximum) for continuous numeric variables, and categorical variables are expressed as participant count and percentage (\%). As a result of Goodness of Fit tests, whether parametric test statistical assumptions were met and the significance of the difference in terms of the continuous numerical variables was evaluated with Independent Samples t-test (Student's t-test). The significance of the difference in terms of continuous numerical variables in which parametric test statistic assumptions were not met was examined with 
the Mann-Whitney $\mathrm{U}$ test when the number of independent groups was 2 . Whether the continuous numerical variables had statistically significant correlations was examined using Pearson's correlation test. Categorical data were evaluated using Pearson's chi-square test. The data were analyzed using IBM SPSS Statistics 23 (IBM Corporation, Armonk, NY, USA) package program. P-values $<0.05$ were considered statistically significant.

\section{Results}

The HG group and the healthy control group were compared in terms of demographic and clinical characteristics and the results are presented in Table 1. The mean age of the HG group was 28.17 ( $S D \pm 5.96)$ years, and that of the healthy control group was 29.45 ( $S D \pm 5.83$ ) years; no statistically significant differences were detected between the groups in terms of age $(p=0.185)$. Statistically significant differences were detected between the groups in terms of education durations ( $p=0.007$ ). The education period of the HG group (12 years) was more than that of the control group (10 years). Statistically significant differences were detected between the groups in terms of educational status ( $\mathrm{p}=0.043), 41.5 \%$ were university graduates in the HG group, and $46 \%$ of the control group were primary school graduates.

No statistically significant differences were detected between the groups in terms of the number of pregnancies (gravida) $(\mathrm{p}=0.060)$. Statistically significant differences were detected between the groups in terms of the number of pregnancies (parity) that resulted in childbirth. The reason for the difference was that parity was higher in the control group ( $\mathrm{p}=0.030)$. No statistically significant differences were detected between the groups in terms of gestational weeks ( $\mathrm{p}=0.880$ ). No statistically significant differences were detected between the groups in terms of the presence of additional disease $(\mathrm{p}=0.990)$, surgical history ( $\mathrm{p}=0.900)$, family history of hyperemesis $(\mathrm{p}=0.148$ ), economic status ( $\mathrm{p}=0.050)$, working status $(\mathrm{p}=0.062)$, and the house lived ( $\mathrm{p}=0.608)$.

Statistically significant differences were detected between the groups in terms of whether the residential area was a city center or district $(\mathrm{p}=0.001)$; the distribution in this respect was similar in the control group. Three-quarters (76.7\%) of the HG group reported that they lived in the city center. Statistically significant differences were detected between the groups in terms of the distribution of the family structure $(\mathrm{p}=0.016)$. Approximately $60 \%$ of the control group stated that they lived with their spouse and children; $50 \%$ of the hyperemesis group lived with their spouse, and 34.5\% lived with their spouses and children. No statistically significant differences were detected between the groups in terms of alcohol use $(\mathrm{p}=0.260)$. Statistically significant differences were detected between the groups in terms of smoking $(\mathrm{p}=0.007)$. There were no smokers in the HG group; however, $11.3 \%$ of the control group said that they smoked.

Table 1. Demographic data of the study and control group

\begin{tabular}{|c|c|c|c|c|c|}
\hline & \multicolumn{2}{|c|}{$\begin{array}{l}\text { HG group } \\
(n=60)\end{array}$} & \multicolumn{2}{|c|}{$\begin{array}{l}\text { Healthy control } \\
\text { group }(n=97)\end{array}$} & \multirow[t]{2}{*}{$p$} \\
\hline & $\mathrm{n}$ & $\%$ & $\mathrm{n}$ & $\%$ & \\
\hline \multicolumn{6}{|l|}{ Age } \\
\hline $18-30$ & 44 & 73.3 & 57 & 58.7 & \multirow{2}{*}{$0.185^{a}$} \\
\hline $31-43$ & 16 & 26.7 & 41 & 42.3 & \\
\hline Mean & \multicolumn{2}{|c|}{28.17} & \multicolumn{2}{|l|}{29.45} & \\
\hline SD & \multicolumn{2}{|c|}{5.96} & \multicolumn{2}{|l|}{5.83} & \\
\hline
\end{tabular}

Education duration (years)

\begin{tabular}{|c|c|c|c|c|c|}
\hline Median/min-max & $12(0-18)$ & & $12(5-18)$ & & $0.007^{\mathrm{b}}$ \\
\hline \multicolumn{6}{|c|}{ Educational status } \\
\hline Illiterate & 1 & 1.5 & 0 & 0 & \multirow{5}{*}{$0.043^{c}$} \\
\hline Primary school & 16 & 27 & 44 & 46 & \\
\hline High school & 16 & 27 & 29 & 31 & \\
\hline University & 23 & 41.5 & 21 & 22 & \\
\hline $\begin{array}{l}\text { Post-graduate/ } \\
\text { doctorate }\end{array}$ & 2 & 3 & 1 & 1 & \\
\hline \multicolumn{6}{|l|}{ Economic status } \\
\hline Low & 3 & 5 & 6 & 6.2 & \multirow[t]{4}{*}{$0.050^{c}$} \\
\hline Moderate & 25 & 41.7 & 61 & 62.9 & \\
\hline Good & 30 & 50 & 28 & 28.9 & \\
\hline Very good & 2 & 3.3 & 2 & 2.1 & \\
\hline \multicolumn{6}{|l|}{ Working status } \\
\hline Working & 24 & 40 & 25 & 25.8 & \multirow{2}{*}{$0.062^{c}$} \\
\hline Not working & 36 & 60 & 72 & 74.2 & \\
\hline \multicolumn{6}{|l|}{ Residence } \\
\hline City center & 46 & 76.7 & 49 & 50.5 & \multirow{2}{*}{$0.001^{c}$} \\
\hline Rural area & 14 & 23.3 & 48 & 49.5 & \\
\hline \multicolumn{6}{|l|}{ Family structure } \\
\hline Living with spouse & 29 & 50 & 26 & 28.3 & \multirow[b]{2}{*}{$0.016^{c}$} \\
\hline $\begin{array}{l}\text { Living with spouse } \\
\text { and children }\end{array}$ & 20 & 34.5 & 55 & 59.8 & \\
\hline Extended family & 9 & 15.5 & 10 & 10.9 & \\
\hline Alone & 0 & 0 & 1 & 1.1 & \\
\hline \multicolumn{6}{|l|}{ Gravida } \\
\hline Median/min-max & \multicolumn{2}{|l|}{$1(1-6)$} & \multicolumn{2}{|l|}{$2(1-5)$} & $0.060^{\mathrm{b}}$ \\
\hline \multicolumn{6}{|l|}{ Parity } \\
\hline Median/min-max & \multicolumn{2}{|l|}{$0(0-3)$} & \multicolumn{2}{|l|}{$1(0-4)$} & $0.030^{\mathrm{b}}$ \\
\hline \multicolumn{6}{|l|}{ Gestational week } \\
\hline Median/min-max & \multicolumn{2}{|l|}{$8(5-39)$} & \multicolumn{2}{|l|}{$9(5-42)$} & $0.880^{\mathrm{b}}$ \\
\hline \multicolumn{6}{|l|}{ Additional disease } \\
\hline Yes & 8 & 13.3 & 13 & 13.4 & \multirow{2}{*}{$0.990^{c}$} \\
\hline No & 52 & 86.7 & 84 & 86.6 & \\
\hline \multicolumn{6}{|l|}{ Surgical history } \\
\hline Yes & 18 & 31.6 & 26 & 30.6 & \multirow{2}{*}{$0.900^{c}$} \\
\hline No & 39 & 68.4 & 59 & 69.4 & \\
\hline \multicolumn{6}{|l|}{ HG family history } \\
\hline Yes & 9 & 15 & 23 & 24.7 & 0 \\
\hline No & 51 & 85 & 70 & 75.3 & $0.148^{\circ}$ \\
\hline Alcohol & & & & & \\
\hline Yes & 0 & 0 & 3 & 2.1 & 0260 \\
\hline No & 60 & 100 & 95 & 97.9 & $0.260^{\circ}$ \\
\hline Smoking & & & & & \\
\hline Yes & 0 & 0 & 11 & 11.3 & \\
\hline No & 60 & 100 & 86 & 88.7 & $0.007^{c}$ \\
\hline
\end{tabular}


When the prevalence of state and trait anxiety was evaluated between the groups, it was found that $66.7 \%$ of the HG group had a higher trait anxiety level (TAS>41), and $51.7 \%$ had a high trait anxiety level (SAS>41). It was also found that $61.9 \%$ of the control group had a high trait anxiety level (TAS>41), and $38.1 \%$ had a high state anxiety level (SAS>41).

According to the results of the Mann-Whitney U test, significant differences were detected between the HG group and the healthy controls in terms of the RSA perception of self $(\mathrm{U}=2385.00$, $\mathrm{p}=0.044)$ and Perception of Future $(\mathrm{U}=2350.50, \mathrm{p}=0.030)$ subdimensions. It was found that the perception of self and perception of future scores of the healthy control group were higher. No significant differences were detected between the groups in terms of RSA total scores and other sub-dimensions (Table 2). No statistically significant differences were detected between the groups in terms of the STAI total scores $(\mathrm{t}=1.54, \mathrm{p}=0.125)$, and the STAI sub-dimensions, which were state anxiety $(\mathrm{t}=1.76, \mathrm{p}=0.080)$ and trait anxiety ( $\mathrm{t}=0.85, \mathrm{p}=0.398$ ) (Table 3 ).
The correlation coefficients among the variables of the groups are given in Table 4. A positive and significant relation was detected between education durations and perception of self $(\mathrm{r}=0.43, \mathrm{p}=0.001)$ and perception of future $(\mathrm{r}=0.40, \mathrm{p}=0.002)$ scores, and between state anxiety, age, and STAI total score $(\mathrm{r}=0.38, \mathrm{p}=0.003)$ in the HG group $(\mathrm{r}=0.43, \mathrm{p}=0.001)$. A significantly positive relation was detected between gestational week and structural style $(r=0.27, p=0.039)$, and a significantly negative relation was detected between state anxiety $(r=-0.31$, $\mathrm{p}=0.017)$ and STAI total scores $(\mathrm{r}=-0.26, \mathrm{p}=0.010)$ in the HG group. The relations between RSA total scores, sub-dimensions of perception of self, perception of future, structural style, social competence, and family agreement and trait anxiety and STAI in the HG group were negative and significant. The relations between RSA total scores, perception of self, perception of future, state anxiety, trait anxiety, and STAI total scores were also negative and significant in the healthy control group. A negative and significant relation was also detected between social competence, trait anxiety, and STAI total scores.

Table 2. Mann-Whitney U test results of total RSA Sub-dimension scores of the hyperemesis and healthy control group

\begin{tabular}{|c|c|c|c|c|c|c|}
\hline & \multicolumn{2}{|c|}{ Hyperemesis group $(n=60)$} & \multicolumn{2}{|c|}{ Healthy control group $(n=97)$} & \multirow[b]{2}{*}{$\mathrm{U}$} & \multirow[b]{2}{*}{$\mathrm{p}$} \\
\hline & $\begin{array}{l}\text { Rank } \\
\text { (median) }\end{array}$ & $\begin{array}{l}\text { Sum } \\
(\min -\max )\end{array}$ & $\begin{array}{l}\text { Rank } \\
\text { (median) }\end{array}$ & $\begin{array}{l}\text { Sum } \\
(\min -\max )\end{array}$ & & \\
\hline \multirow{2}{*}{ Perception of self } & 70.25 & 4215.00 & 85.16 & 8346.00 & \multirow{2}{*}{2385.00} & \multirow{2}{*}{$0.044 *$} \\
\hline & 22.5 & $6-30$ & 26 & $8-30$ & & \\
\hline \multirow{2}{*}{ Perception of future } & 69.68 & 4180.50 & 85.52 & 8380.50 & \multirow{2}{*}{2350.50} & \multirow{2}{*}{$0.030 *$} \\
\hline & 16 & $6-20$ & 16 & $4-20$ & & \\
\hline \multirow{2}{*}{ Structural style } & 72.77 & 4366.00 & 83.62 & 8195.00 & \multirow{2}{*}{2536.00} & \multirow{2}{*}{0.139} \\
\hline & 16 & $4-20$ & 16 & $4-20$ & & \\
\hline \multirow{2}{*}{ Social competence } & 76.28 & 4576.50 & 81.47 & 7984.50 & \multirow{2}{*}{2746.50} & \multirow{2}{*}{0.483} \\
\hline & 23 & $10-30$ & 26 & $10-30$ & & \\
\hline \multirow{2}{*}{ Family agreement } & 75.28 & 4517.00 & 82.08 & 8044.00 & \multirow{2}{*}{2684.00} & \multirow{2}{*}{0.348} \\
\hline & 26 & $14-30$ & 26 & $12-30$ & & \\
\hline \multirow{2}{*}{ Social resources } & 70.58 & 4235.00 & 84.96 & 8326.00 & \multirow{2}{*}{2405.00} & \multirow{2}{*}{0.051} \\
\hline & 31 & $19-35$ & 31 & $15-35$ & & \\
\hline \multirow{2}{*}{ RSA total } & 71.52 & 4291.00 & 84.39 & 8270.00 & \multirow{2}{*}{2461.00} & \multirow{2}{*}{0.086} \\
\hline & 134.5 & $19-35$ & 141 & $76-165$ & & \\
\hline
\end{tabular}

RSA: The resilience scale for adults, min-max: Minimum-maximum, ${ }^{*} \mathrm{p}<0.05$

Table 3. T-test results of total and sub-dimensions of state-trait anxiety inventory of the hyperemesis and healthy control group

\begin{tabular}{|c|c|c|c|c|c|c|}
\hline & \multicolumn{2}{|c|}{ Hyperemesis group $(n=60)$} & \multicolumn{2}{|c|}{ Healthy control group ( $n=97)$} & $\mathrm{t}$ & $\mathrm{p}$ \\
\hline State anxiety & 42.05 & 9.73 & 39.13 & 10.29 & 1.76 & .080 \\
\hline Trait anxiety & 44.93 & 7.61 & 43.84 & 7.92 & 0.85 & .398 \\
\hline STAI total & 86.58 & 191.96 & 82.97 & 16.31 & 1.54 & .125 \\
\hline
\end{tabular}


Table 4. Pearson correlation coefficients among the variables

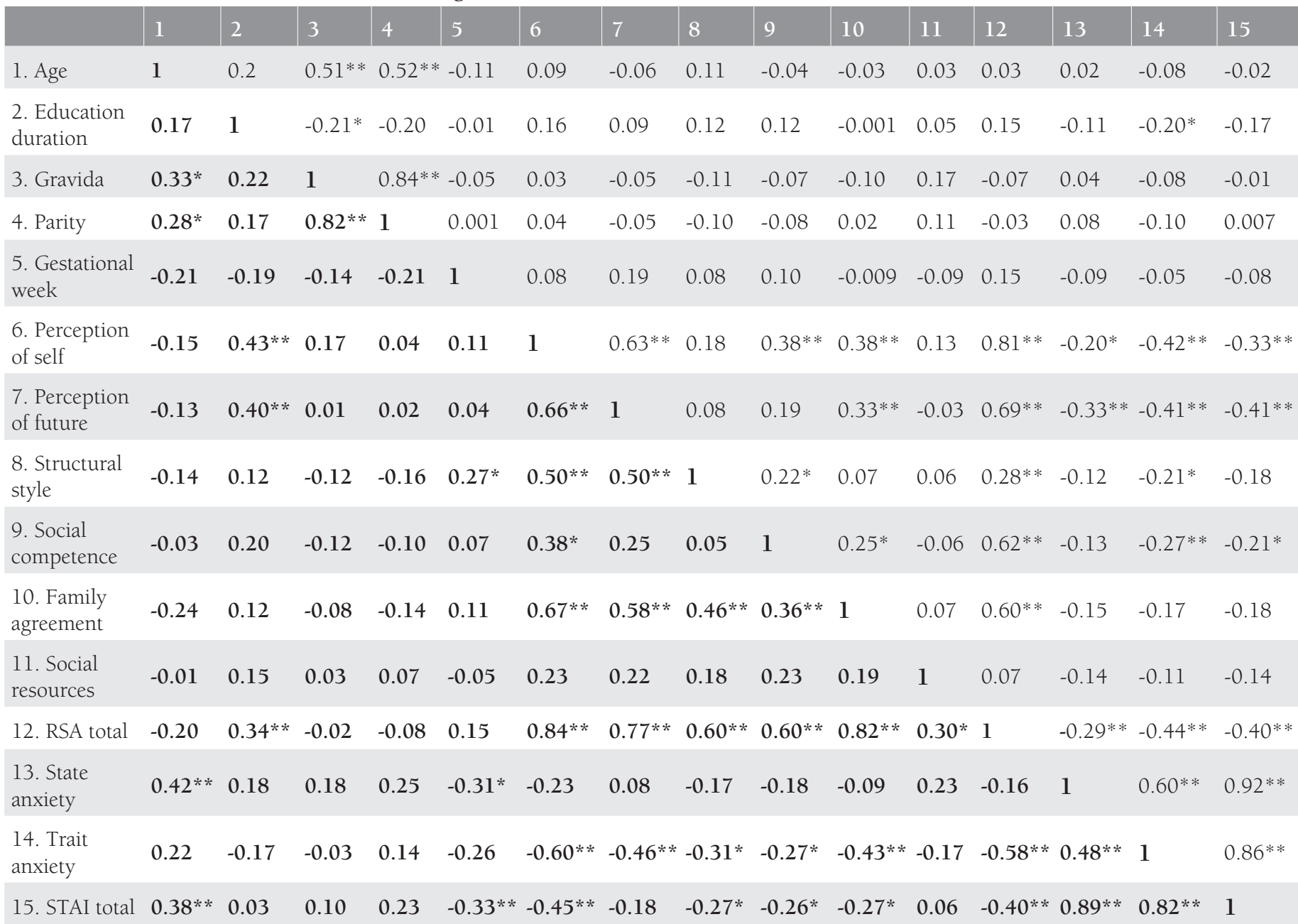

RSA: The resilience scale for adults, STAI: State-trait anxiety inventory

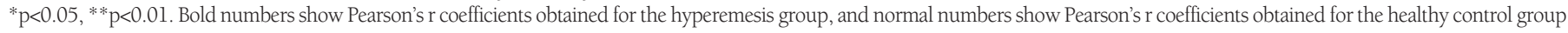

\section{Discussion}

In the present study, 60 women who were diagnosed as having HG in the first 3 months of their pregnancies, and 97 healthy pregnant women who had similar characteristics as the HG group were compared in terms of PR and anxiety levels. No significant differences were detected between the groups in terms of anxiety levels. PR was measured using RSA, and a significant difference was detected between the groups in terms of Perception of Self and perception of future, which are the sub-dimensions. The HG group had lower perception of self and perception of future scores than the healthy control group. We found that as age increased, state anxiety scores also increased, and state anxiety scores decreased as the gestational week progressed in the HG group. Negative and significant correlations were detected between the PR scores and anxiety scores of both groups.

The HG and control groups were compared according to some sociodemographic variables. We found that age, gravida, gestational week, economic status, and working status did not differ significantly between the groups. These findings are consistent with the results of similar studies in the literature ${ }^{(19,25-27)}$. In the present study, a significant difference was found between the HG and the control group in terms of educational status. The percentage of university graduates in the HG group was higher than in the control group. However, previous results regarding education status are conflicting: according to some comparative studies, there was no difference between HG and control groups in terms of educational status ${ }^{(19,25-27)}$, but one study reported that the HG group had a lower education level than the healthy group ${ }^{(28)}$. Likewise, results regarding parity in women with HG are controversial. Our findings showed significantly lower parity in the HG group than in the control group. In line with our findings, some studies reported a nulliparity risk factor for HG, and also primiparous women needed hospital care more because of $H G^{(29,30)}$. By contrast, some studies found no difference in parity between HG and healthy groups ${ }^{(27,28)}$. When comparing family structure, we found a difference between the HG and control groups. A higher percentage of the HG group lived with their 
spouses, whereas a higher percentage of the control group lived with their spouses and children. This finding is parallel to the parity result. In other words, the higher parity in the control group was compatible with living with a spouse and children in terms of family structure.

In the present study, no significant differences were detected between the groups in terms of state and trait anxiety and STAI total scores. An important part of the literature reported that levels of depression and anxiety increased in women with $H G^{(31-33)}$. Previous studies comparing women with $\mathrm{HG}$ and healthy controls reported that the HG group had higher anxiety scores $^{(19,25-27)}$. Although it is expected that stubborn nausea and vomiting decrease the quality of life significantly and impair the perception of health of the person, the present study found no significant differences in terms of anxiety levels. Women with HG had higher anxiety, depression, and stress levels when they were newly admitted to hospital and their anxiety, depression; and stress levels decreased with time ${ }^{(34)}$. In the present study, the fact that the women with HG were hospitalized may have reduced their anxiety levels. However, anxiety and depression may increase in pregnancy, and pregnancy is a risk factor for depression and anxiety ${ }^{(35-37)}$. Besides, different scales were used to measure the anxiety levels of pregnant women with HG in previous studies (e.g. Beck Anxiety inventory, SCL-90, SCIDII), which may account for the disparity between our findings and those in the literature.

In the literature, no studies were detected dealing with PR in pregnant women with HG. Studies were focused on the relations of PR in pregnant women with other psychological factors and did not include any control groups ${ }^{(20,38,39)}$. We found that the RSA subscales, perception of self, and perception of future scores of the HG group were significantly lower in the HG group than in the control group. According to Friborg et al. ${ }^{(21)}$, self-perception and future perception, which represent personal strength, are associated with emotional resilience, which is among personality traits. Also, future perception is considered to be associated with the responsibility of the personality. The lower perceptions of the HG group detected in the present study regarding themselves and the future compared with the control group may show that they faced difficulties emotionally with a sense of responsibility for their future.

PR is a protective factor for the mother's psychological health ${ }^{(39)}$, and points at internal and interpersonal protective resources, which may facilitate the adaptation and tolerance to stress ${ }^{(21)}$. A negative relation was reported in previous studies between prenatal stress, depression, and anxiety levels of pregnant women and their PR scores ${ }^{(20,38-40)}$. These results are consistent with the negative correlation finding between PR and anxiety scores in both groups in our study. Our findings indicate that as depression, anxiety, and stress levels increase during pregnancy, PR scores decrease. However, it is interesting that perception of self, perception of future, and other RSA sub-dimensions were negatively correlated with trait anxiety and total anxiety scores, not state anxiety scores in the HG group. On the other hand, PR scores were associated with both state and trait anxiety scores in the healthy group. This means that trait anxiety, known as a personal characteristic, is associated with PR in the HG group. We also found that anxiety levels decreased as the gestational week of the HG group increased. In other words, it means that there is a decrease in anxiety in pregnant women with HG towards the end of the first trimester.

Studies show that strong PR is associated with psychological well-being ${ }^{(11,42)}$. PR is effective in dealing with physical pain, reducing negative attitudes towards pain, and strengthening psychological well-being and positive emotions ${ }^{(43,44)}$. Coping with HG characterized by persistent nausea and vomiting and increasing the PR resources of women diagnosed with HG will improve their psychological well-being. PR may increase resistance to the negative effect of prenatal stress on anxiety and depression $^{(41)}$. PR in pregnant women with HG is recommended to be investigated together with other variables that may be related in future studies (e.g. coping with stress, self-esteem, self-sufficiency). However, PR can be considered as a factor that needs to be dealt with in intervention programs aimed at improving psychological health in pregnant women.

\section{Study Limitations}

The small sample size of the study caused a limitation in terms of the generalization of the findings. Our study is the first to compare pregnant women with HG and healthy pregnant women in terms of PR. It was found that the HG group was significantly different from healthy pregnant women in terms of perception of self and perception of future. No significant differences were detected between the groups in terms of anxiety levels. The cross-sectional design of the study was another limitation. More significant associations may be obtained in future studies in which HG and control groups are followed up in terms of anxiety and PR in the third trimester. Also, planning future studies with a longitudinal design with pregnant women with HG will provide a better understanding and explain the psychosocial dimension of HG.

\section{Conclusion}

It is predictable that when a complication such as $\mathrm{HG}$ is added during pregnancy it can increase the anxiety and fear of the person during a period that is believed to increase the probability of anxiety and depression. As our study showed that self-perception and future perception were lower in the HG group, these patients should be evaluated multidisciplinary by an obstetrician, psychologist, and social worker. For this reason, healthcare professionals must be aware of the fact that extra psychological support may be needed during the treatment and follow-up of the patient. Psychological support should be provided to increase PR owing to the future anxiety and decreased self-perception of the patient. Psychologically supportive treatment during follow-up may significantly reduce 
the severity of the disease. We also think that the relatives of the patient can have a positive effect. The support of the relatives in reducing the patient's anxiety and increasing the perception of value will contribute to the recovery process.

\section{Ethics}

Ethics Committee Approval: The required approvals for the study were obtained from the University of Health Sciences Turkey, Ankara Etlik Zübeyde Hanım Women's Health Training and Research Hospital (decision number: 90057706-799, date: 19.02.2019).

Informed Consent: Informed consent of the participants was obtained.

Peer-review: Externally peer-reviewed.

\section{Authorship Contributions}

Concept: A.C.K., Design: A.C.K., S.E., Data Collection or Processing: B.S.Ö., Analysis or Interpretation: B.S.Ö., A.B., S.E., Literature Search: G.A., I.B.Ç., Writing: B.E., M.V.

Conflict of Interest: The authors report no conflict of interest. Financial Disclosure: Authors have no financial interests about the research.

\section{References}

1. Ebrahimi N, Maltepe C, Einarson A. Optimal management of nausea and vomiting of pregnancy. Int J Womens Health 2010;2:241-8.

2. Matthews A, Haas DM, O'Mathúna DP, Dowswell T. Interventions for nausea and vomiting in early pregnancy. Cochrane Database Syst Rev 2015; 9:CD007575. doi: 10.1002/14651858.CD007575. pub4.

3. Chou FH, Chen CH, Kuo SH, Tzeng YL. Experience of Taiwanese women living with nausea and vomiting during pregnancy. J Midwifery Womens Health 2006;51:370-5.

4. Bottomley C, Bourne T. Management strategies for hyperemesis. Best Pract Res Clin Obstet Gynaecol 2009;23:549-64.

5. Jewell D, Young G. Interventions for nausea and vomiting in early pregnancy. Cochrane Database Syst Rev 2003;8:CD000145. doi: 10.1002/14651858.CD000145.

6. Tamay AG, Kuşçu NK. Hyperemesis gravidarum: current aspect. J Obstet Gynaecol 2011;31:708-12.

7. Festin M. Nausea And Vomiting In Early Pregnancy. BMJ Clin Evid 2009;2009:1405.

8. D'Orazio LM, Meyerowitz BE, Korst LM, Romero R, Goodwin TM. Evidence against a link between hyperemesis gravidarum and personality characteristics from an ethnically diverse sample of pregnant women: a pilot study. J Womens Health (Larchmt) 2011;20:137-44.

9. Pirimoglu ZM, Guzelmeric K, Alpay B, Balcik O, Unal O, Turan MC. Psychological factors of hyperemesis gravidarum by using the scl-90-r questionnaire. Clin Exp Obstet Gynecol 2010;37:56-9.

10. Power Z, Thomson AM, Waterman H. Understanding the stigma of hyperemesis gravidarum: qualitative findings from an action research study. Birth 2010;37:237-44.

11. Heitmann K, Nordeng H, Hownen GC, Solheimsnes A, Holst L. The burden of nause and vomiting during pregnancy severe impacts on quality of life, daily life functioning and willing nessto become pregnant again- result from a cross-sectional study. BMC Pregnancy Childbirth 2017;17:75.

12. Luthar SS, Cicchetti D, Becker B. The construct of resilience: A critical evaluation and guidelines for future work. Child Dev 2000;71:543-62.

13. Friborg O, Hjemdal O, Rosenvinge JH, Martinussen M. A new rating scale for adult resilience: what are the central protective resources behind healthy adjustment? Int J Methods Psychiatr Res 2003; 12:65-76

14. Campbell-Sills L, Cohan SL, Stein MB. Relationship of resilience to personality, coping, and psychiatric symptoms in young adults. Behav Res Ther 2006;44:585-99.

15. Teixeira C, Figueiredo B, Conde A, Pacheco A, Costa R. Anxiety and depression during pregnancy in women and men. J Affect Disord 2009;119:142-8.

16. Bhat NA, Hassan R, Shafiq M, Sheikh S. Sociodemographic factors: a major predictor of anxiety and depression among pregnant women. Delhi Psychiatry J 2015;18:86-94.

17. Verberg MFG, Gillott DJ, Al-Fardan N, Grudzinskas JG. Hyperemesis gravidarum, a literature review. Hum Reprod Update 2005;11:527-39.

18. Seng JS, Schrot JA, van De Ven C, Liberzon I. Service use data analysis of pre-pregnancy psychiatric and somatic diagnoses in women with hyperemesis gravidarum. J Psychosom Obstet Gynaecol 2007;28:209-17.

19. Uguz F, Gezginc K, Kayhan F, Cicek E, Kantarci AH. Is hyperemesis gravidarum associated with mood, anxiety and personality disorders: a case-control study. Gen Hos Psychiatry 2012;34:398402.

20. Li G, Kong L, Zhou H, Kang X, Fang Y, Li P. Relationship between prenatal maternal stress and sleep quality in Chinese pregnant women: the mediation effect of resilience. Sleep Med 2016;25:8-12.

21. Friborg O, Barlaug D, Martinussen, M, Rosenvinge JH, Hjemdal O. Resilience in relation to personality and intelligence. Int J Methods Psychiatr Res 2005;14:29-42.

22. Basim HN, Cetin F. The reliability and validity of the resilience scale for adults. Türk Psikiyatri Derg 2011;22:104-14.

23. Spielberger CD, Gorsuch RL, Lushene RE. STAI Manual for the State-Trait Anxiety Inventory. Palo Alto, California: Consulting Psychologists' Press; 1970.

24. Oner N, LeCompte WA. Durumluk-sürekli kaygı envanteri el kitabı. İstanbul: Boğaziçi Üniversitesi Yayınları; 1985.

25. Senturk MB, Yıldız G, Yıldız P, Yorguner N, Çakmak Y. The relationship between hyperemesis gravidarum and maternal psychiatric well-being during and after pregnancy: controlled study. J Matern Fetal Neonatal Med 2017;30:1314-9.

26. Ylldırım E, Demir E. The relationship of hyperemesis gravidarum with sleep disorders, anxiety and depression. J Obstet Gynaecol 2019;39:793-8.

27. Şimşek Y, Çelik Ö, Yılmaz E, Karaer A, Yıldırım E, Yoloğlu S. Assessment of anxiety and depression levels of pregnant women with hyperemesis gravidarum in a case-control study. J Turk Ger Gynecol Assoc 2012;13:32-6.

28. Topalahmetoğlu Y, Altay MM, Akdağ Cırık D, Tohma YA, Çolak E, Çoşkun B, et al. Depression and anxiety disorder in hyperemesis gravidarum: a prospective case-control study. Turk J Obstet Gynecol 2017;14:214.

29. Fiaschi L, Nelson-Piercy C, Tata LJ. Hospital admission for hyperemesis gravidarum: a nationwide study of occurrence, reoccurrence and risk factors among 8.2 million pregnancies. Hum Reprod 2016;31:1675-84. 
30. Fell DB, Dodds L, Joseph KS, Allen VM, Butler B. Risk factors for hyperemesis gravidarum requiring hospital admission during pregnancy. Obstet Gynecol 2006;107:277-84.

31. Bozzo P, Einarson TR, Koren G, Einarson A. Nausea and vomiting of pregnancy (NVP) and depression: cause or effect? Clin Invest Med 2011;34:245-48.

32. Kjeldgaard HK, Eberhard-Gran M, Benth JS, Vikanes ÅV. Hyperemezis gravidarum and the risk of emotional distress during and after pregnancy. Arch Womens Ment Health 2017;20:747-56.

33. Koken G, Yllmazer M, Coşar E, Kır Sahin F, Cevrioglu S, Gecici Ö. Nausea and vomiting in early pregnancy:relationship with anxiety and depression. J Psychosom Obstetr Gynaecol 2008;29:91-5.

34. Tan PC, Zaidi SN, Azmi N, Omar SZ, Khong SY. Depression, anxiety, stress and hyperemesis gravidarum: temporal and case controlled correlates. PLoS One 2014;9:e92036. doi: 10.1371/ journal.pone.0092036.

35. Akbaş E, Vırıt O, Kalenderoğlu A, Savaş AH, Sertbaş G. Gebelikte Sosyodemografik Değişkenlerin Kaygı ve Depresyon Düzeyleriyle İlişkisi. Arch Neuropsychiatry 2008;45:85-91.

36. Arslan B, Arslan A, Kara S, Öngel K, Mungan MT. Risk factors for pregnancy anxiety and depression: assessment in 452 cases. Tepecik Eğitim Hastanesi Dergisi 2011;21:79-84.

37. Yücel P, Çayır Y, Yücel M. Birinci trimester gebelerde depresyon ve anksiyete bozukluğu. Klinik Psikiyatri 2013;16:83-7.
38. Bahadır Yılmaz E, Şahin E. Factors associated with prenatal distress levels of pregnant women. J Psychiatr Nurs 2019;10:197-203.

39. Ma X, Wang Y, Hu H, Tao XG, Zhang Y, Shi H. The impact of resilience on prenatal anxiety and depression among pregnant women in Shanghai. J Affect Disord 2019;250:57-64.

40. Kishore MT, Satyanarayana V, Ananthanpillai ST, Desai G, Bhaskarapillai B, Thippeswamy H, et al. Life events and depressive symptoms among pregnant women in India: Moderating role of resilience and social support. Int J Soc Psychiatry 2018;64:570-7.

41. Mak WW, Ng IS, Wong CC. Resilience: enhancing well-being through the positive cognitive triad. J Couns Psychol 2011;58:6107.

42. Mayordomo T, Viguer P, Sales A, Satorres E, Meléndez JC. Resilience and coping as predictors of well-being in adults. J Psychol 2016;150:809-21.

43. Karoly P, Ruehlman LS. Psychological "resilience" and its correlates in chronic pain: findings from a national community sample. Pain 2006;123:90-7.

44. Ong AD, Zautra AJ, Reid MC. Psychological resilience predicts decreases in pain catastrophizing through positive emotions. Psychol Aging 2010;25:516-23. 